\title{
IMAGENS DA VIOLÊNCIA ENTRE TRANSGRESSÕES E TENSÕES
}

\section{APRESENTAÇÃO}

O número 35 da Revista Eletrônica Literatura e Autoritarismo, referente ao primeiro semestre de 2020, apresenta uma articulação entre vários temas e questões relevantes que muitas vezes ficam em um segundo plano, mas que se somam para refletir e discutir a partir da produção literária. Com o título Imagens da violência entre transgressões e tensões, a presente edição amplia a perspectiva de imagem do seu caráter representativo para o tangível ao considerar as experiências com base na constante presença da violência. O primeiro artigo, de autoria de Andre Rezende Benatti, esclarece que a literatura na América Latina possui uma profunda relação com a violência. Em O REAL, O VIOLENTO E A VINGANÇA NO CONTO "PUTAS ASESINAS", DE ROBERTO BOLAÑO, Benatti defende que "as violências fizeram e ainda fazem parte do cotidiano nas América Latina” para enfatizar seu percurso de leitura da obra de Bolaño. Diferencia o mote da vingança presente no conto $\mathrm{Pu}$ tas asesinas de outras obras ao considerar que "o algoz se perde. Trata-se de uma história de vingança na qual a vítima vingativa não tem um alvo certo, não tem um nome ou coisa que o valha que deva ser objeto do ato vingativo", naturalizando, assim, a violência e a crueldade como um ato de satisfação própria e partes constitutivas da narradora.

TENSÕES ÉTNICO-CULTURAIS NA LITERATURA DE CABO VERDE: ESPACIALIDADES FEMININAS EM “LIBERDADE ADIADA", DE DINA SALÚSTIO, de Paulo Freitas Gomes e Vanessa Riambau Pinheiro, discute a reconfiguração do imaginário insular de Cabo Verde a partir do conto de Dina Salústio. Partindo da compreensão de que o colonialismo se constitui como um projeto de soberania política e social eurocêntrica, Gomes e Pinheiro discutem o projeto nativista que visava a fusão de civilizações para enfatizarem as tensões e conflitos a partir da noção de identidade ambígua e adentrarem o espaço de análise do conto Liberdade adiada que "é uma narrativa breve, porém intensa. Em poucas linhas consegue transitar por vários temas que tocam a vida da mulher cabo-verdiana. A brevidade é um traço distintivo das narrativas integrantes da obra Mornas eram as noites (1994), entretanto, não se estreita à extensão do texto, mas soa como crítica ao

Marcela da Fonseca Ferreira e Felipe dos Santos Matias trazem a discussão sobre a violência no ensaio intitulado A REPRESENTAÇÃO DA VIOLÊNCIA CONTRA A MULHER NO CONTO EL SOLITARIO, DE HORACIO QUIROGA. Os conceitos e significados que envolvem gênero, considerando a perspectiva do feminino, e violência parecem indissociáveis, visto as sólidas relações entre sexo e poder presentes em grande parte das produções literárias. Ferreira e Matias destacam que a violência do homem sobre a mulher é legitimada na narrativa de Quiroga, visto que "no conto El solitario, há que se fazer uma ressalva em relação à conduta do narrador, em terceira pessoa, no texto de Quiroga, visto 
que o mesmo se coloca, ao longo da narrativa, nitidamente a favor de Kassim, tentando passar para o leitor a ideia de que María era uma mulher fútil e interesseira."

HISTÓRIA E SEUS SILÊNCIOS: HONRARÁS A TU PADRE Y A TU MADRE, DE CRISTINA FALLARÁS, é o artigo de Joyce Rodrigues Ferraz-Infante que adentra o campo da história e suas relações com a produção literária a partir das memórias de "uma família da classe alta espanhola, que, a fim de representar uma vida conjugal aparentemente estável e feliz, optou por calar traumas e feridas de um passado marcado pela Guerra Civil e pela ditadura de Francisco Franco." As vozes que foram encobertas pela censura, pela guerra e pela violência dentro e fora do ambiente familiar ecoam por meio da narrativa. Cristina Fallarás também é o nome da protagonista, o que não é uma coincidência conforme a análise de Ferraz-Infante, que "se propõe a desvelar e revelar os silêncios que a privaram de um avô paterno e a questionar os valores que lhe transmitiram os avós maternos". O dia 05 de dezembro de 1936 - "el punto en el que se cruzan todas y cada una de sus partes, desde donde parten las cosas hacia el futuro y hacia el pasado, y que sin ese punto no serían nada" - é o ponto de partida que sustenta os questionamentos e articula os períodos históricos na Espanha e a constante marca da violência e do horror.

As lembranças e as memórias são elementos que se cruzam e se desconstroem para demonstrar impressões sobre a experiência humana a partir das tensões que emergem entre o que é real e o que é imaginado. O texto de Tiago Ferreira Pereira e Rosani Ketzer Umbach aborda a obra de Kazuo Ishiguro com base nessa problemática de representação das memórias. Em MEMÓRIA INDIVIDUAL E COLETIVA EM 'THE REMAINS OF THE DAY' DE KAZUO ISHIGURO, Pereira e Umbach trazem esse conflito entre a vivência próxima ao toque, sensível aos sentidos e ao trânsito corpóreo que muitas vezes ignora o cenário maior do qual participa, como um mordomo que trabalha em uma mansão e quase nada conhece da vida das pessoas que serve. O protogonista da obra permite que esses sentidos atinjam o leitor, pois a "memória individual de Stevens - suas recordações pessoais - se integra com a memória coletiva - memória do contexto social da I e II Guerras Mundiais. O protagonista, no entanto, parece encontrar dificuldades em alinhar suas lembranças às de outros testemunhos fora de seu círculo social", e é isso que reconfigura a narrativa a partir da "visão subjetiva do mordomo, ou seja, sua memória individual diverge daquela da coletividade".

EU/OUTRO (DES)MASCARADO: TRANSGRESSÕES AUTORAIS EM PUBLICAÇÃO DE FANFICTION, sexto artigo desta edição assinado por Juliene da Silva Marques, traz uma abordagem a partir da Análise do Discurso de linha francesa para refletir sobre a autoria na narrativa Cellbit, a vida com MITW, de Titia_Little. Discutindo o espaço que esse gênero ocupa no cenário atual, Marques explica que a "fanfiction se configura como um universo próprio de narrativa, diferenciando-se e ficando, muitas vezes, à margem das publicações legitimadas socialmente". Ao discutir a produção de uma obra dentro do ambiente colaborativo dos ambientes virtuais, o artigo se propõe a "investigar a transgressão no movimento de autoria que constitui a subjetivação das minorias diante do eu/outro digit(re)al, tendo como base a materialidade discursiva da fanfiction sobre influenciadores digitais".

PUREZA E VIOLÊNCIA: IMAGENS DA INFÂNCIA EM A. VETERANYI, de Dionei Mathias e Juliana Cássia Müller, aborda o romance Por que a criança cozinha na polenta, 
da escritora romena Aglaja Veteranyi, apontando que a obra apresenta "sedimentos biográficos, transformando esses excertos da realidade afetiva em uma complexa estruturação estética, na qual a figura de uma criança migrante protagoniza o enredo." As vivências da infância e suas recordações acompanham o trânsito da protagonista e servem de contraponto para o enfrentamento do medo e dos problemas pelos quais passa. O conflito constante entre a pureza da infância e a violência do mundo adulto causam sensações de desamparo e angústia ao mesmo tempo que são capazes de consolar e dar forças para seguir em frente, pois é nessa "confluência de sentidos produzidos a partir do confronto indesejado com a violência e os processos de apropriação de realidade empreendidos pela criança, [que] a tessitura de identidade assume outras chances de concretização e simbolização".

Fechando esta edição, Gabriel Gustavo dos Santos e Nerynei Meira Carneiro Bellini trazem o artigo A SUPERAÇÃO DO AUTORITARISMO EM JOSÉ J. VEIGA refletindo sobre o contexto histórico e político da obra Sombra de Reis Barbudos. A análise se propõe a recuperar acontecimentos passados a partir das memórias de um menino que atua como protagonista do romance e, na "ativação da memória de um narrador que vivenciou os fatos narrados, o leitor conhece Taitara e toma ciência de sua desolação e abandono, à semelhança de uma cidade fantasma." As associações realizadas a partir da narrativa permitem que os leitores estabeleçam possibilidades de superarem ao menos parte desse ideário de opressão, pois em "Sombras de Reis Barbudos entendemos que a construção labiríntica da cidade simboliza a opressão e a dominação de governantes pérfidos. (...) Paradoxalmente, a presença opressora dos "muros", ou ainda, o enfrentamento dos entraves cerceadores é que impulsiona o ser humano a agir na direção de soluções plausíveis."

Agradecemos a colaboração e a confiança dos autores que disponibilizaram seus textos para comporem esta edição e esperamos que as análises e reflexões aqui apresentadas atinjam leitores visando a ampliação das discussões. 
